\title{
Analisa Erosivitas Lahan Pada DAS Batang Agam Dengan Menggunakan Model SWAT
}

\section{Analysis of Land Erosion in the Batang Agam Watershed Using the SWAT Model}

\author{
Irfan Gustio, Dwi Putri Jingga, Elvi Roza Syofyan \& Chairul Muharis \\ Jurusan Teknik Sipil Politeknik Negeri Padang Kampus Limau Manis Padang 25163 \\ Telp.0751-72590 Fax.0751-72576 Email : irfan.gusto@gmail.com, dwiputrijingga07@gmail.com, \\ syofyan_er@yahoo.co.id
}

\section{ABSTRACT}

Batang Agam River is a river that flows along Bukittinggi City, Agam Regency, Fifty Cities Regency, Tanah Datar Regency, Payakumbuh City and empties into the Batang Sinamar River. The Batang Agam River, which crosses the residential area, is mostly used for agriculture, fisheries, tourism, mining and other activities. Community activities in the area of the Batang Agam River have resulted in a decrease in the function of the river which is characterized by narrowing, silting and pollution of the river. In addition, it is influenced by the ever-changing river water discharge, land conditions and changes that occur in the river channel. In addition, the negative behavior of the community and all their activities around the river basin also triggers damage to the river. This research was conducted to determine the value of land erosivity towards changes in land use area in the Batang Agam watershed, in this study using land cover in 2010, 2014, and 2019 using the Soil and Water Assessment Tool (SWAT) model and manual calculations were carried out using the USLE method as ratio. The analysis consists of four processes, namely watershed delineation, formation of a Hydrologic Response Unit (HRU), formation of climatological data, and finally the simulation process. The results of the HRU analysis showed that the Batang Agam watershed became 7 sub-watersheds, the dominant HRU was primary forest. In the case of Batang Agam, it was found that the level of erosion hazard was in the light category and the erosion value decreased in each review year.

Keywords: Land Use, SWAT, HRU, Erosion, Batang Agam Watershed

\section{PENDAHULUAN}

Aktifitas masyarakat didaerah aliran Sungai Batang Agam telah mengakibatkan penurunan fungsi sungai yang ditandai dengan penyempitan, pendangkalan dan pencemaran sungai. Selain itu dipengaruhi oleh debit air sungai yang selalu berubah, kondisi lahan maupun perubahan yang terjadi dialur sungai. Selain itu perilaku negatif masyarakat dan segala aktifitasnya disekitar daerah aliran sungai ikut memicu terjadinya kerusakan terhadap sungai.

Meningkatnya kuantitas penduduk memberikan pertumbuhan yang signifikan, yang mana menyebabkan kebutuhan tataguna lahan juga meningkat. Peningkatan kebutuhan tataguna lahan ini mengakibatkan penurunan kualitas terhadap lingkungan. Hal ini akan memberikan dampak yang besar tergarap sistem hidrologi DAS. Meningkatnya pertumbuhan penduduk, maka semakin banyak pula lahan yang digarap dan ditata menjadi perumahan, kantor perusahaan dan serana-prasarana lainnya. Sungai yang biasanya mampu menampung air, sekarang tidak biasa lagi menampung debit yang melebihi kapasitasnya. Sehingga menyebabkan terjadi banjir, erosi, dan penumpukan sedimen dibadan sungai.

Karakteristik DAS dapat dihasilkan dari analisis satuan respon hidrologi (Hydrologic Response Unit/HRU). HRU 
merupakan satuan analisis hidrologi yang dibentuk berdasarkan jenis tanah, ketinggian dan lereng, geologi serta penutup lahan. Analisis HRU tersebut dapat menghasilkan fakta dan fenomena keruangan yang ada dalam lingkup hubungan antar subDAS. Perubahan HRU ini biasanya terjadi akibat berkembangnya suatu wilayah yang membutuhkan lahan untuk pemukiman maupun tutupan lahan lainnya.

Berdasarkan latar belakang dan kasus di atas, maka Penulis melakukan penelitian dan penelusuran terhadap DAS Batang Agam dengan menggunakan simulasi permodelan Soil and Water Assessment Tool (SWAT). Model SWAT telah banyak digunakan untuk mengkaji dampak penggunaan lahan suatu DAS terhadap hasil air, namun hasil simulasinya beragam. Penerapan model SWAT dalam skala DAS dengan input data yang cukup beragam dan bersifat kontinyu. Oleh sebab itu, model ini banyak dipilih untuk dikaji dan digunakan untuk menduga debit andalan, nilai erosi dan aliran permukaan sungai di suatu DAS.

Penelitian ini bertujuan untuk mengetahui besarnya pengaruh perubahan tataguna lahan terhadap erosivitas lahan pada DAS Batang Agam dan mengetahui besaran spasial HRU pada masing-masing subDAS Batang Agam.

\section{METODOLOGI}

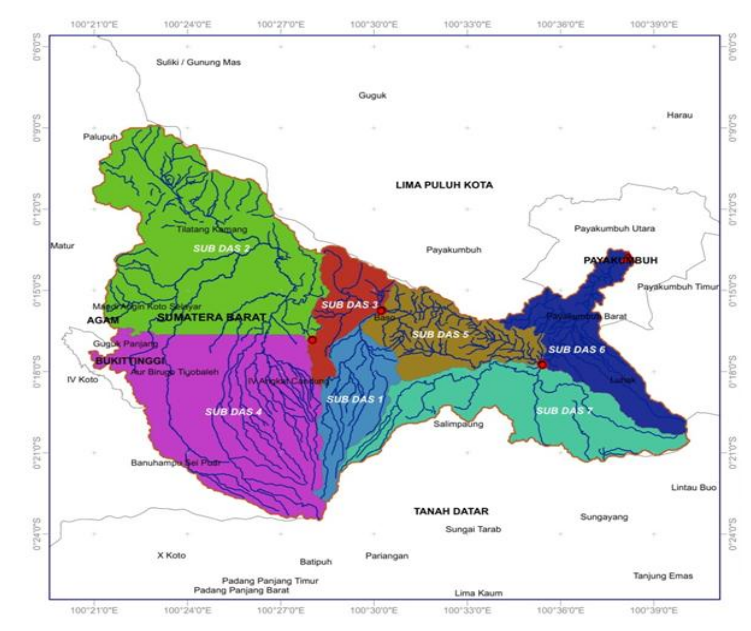

Gambar 1. Peta DAS Batang Agam
Lokasi Penelitian Penelitian ini dilakukan pada DAS Batang Agam, Kecamatan Payakumbuh Utara, Kota Payakumbuh, Provinsi Sumatera Barat. Secara administratif Luas DAS Batang Agam sekitar 462,527 ha yang membentang daerah aliran Sungai Batang Agam yang mengalir sepanjang Kota Bukittinggi, Kabupaten Agam, Kabupaten Lima Puluh Kota, Kabupaten Tanah Datar, Kota Payakumbuh dan bermuara ke Sungai Batang Sinamar.

\section{Alat dan Bahan}

Alat yang dibutuhkan dalam penelitian ini adalah perangkat komputer dengan kebutuhan sebagai berikut:

a. Komputer desktop dengan prosesor yang Peneliti gunakan yaitu Intel Core i5 Nvidia GEFORCE 930Mx.

b. RAM dengan kapasitas \pm 4 GB.

c. Sistem operasi Microsoft Windows 10.

d. Kapasitas Hardisk minimum untuk instalasi dan penyimpanan folder sebesar \pm 1 GB.

e. Software yang terinstall, diantaranya adalah Microsoft Office 2013, Microsoft Framework 4.5.

f. Aplikasi QGIS dan ArcSWAT 2012

Sedangkan untuk bahan-bahan yang dibutuhkan dalam penelitian ini adalah sebagai berikut:

a. Peta DEM dengan resolusi 30 meter dalam bentuk UTM.

b. Data iklim, temperatur, penyinaran matahari, radiasi, solar, dan kecepatan angin.

c. Data Jenis Tanah.

d. Data curah hujan dari tahun 2010 sampai dengan tahun 2019, yang diperoleh dari stasiun Canduang, Tanjung Pati dan Suliki.

e. Data tataguna lahan tahun 2010,2014 dan 2019.

f. Data Sungai. 


\section{Pengelolahan Data Input Dengan pemodelan SWAT}

a. Delineasi daerah Observasi

b. Pembentukan Hydrologic Response

c. Penggabungan HRU dengan Data Iklim

d. Parameterisasi Input Simulasi

\section{Pengelolahan Data Input Dengan Perhitungan Manual metode USLE}

a. Perhitungan erosivitas curah hujan (Rm)

b. Perhitungan nilai erodibilitas tanah (K)

c. Perhitungan nilai kelerengan (Ls)

d. Perhitungan nilai tutupan dan penggunaan lahan $(\mathrm{C})$

e. Perhitungan nilai pengolahan tanah $(\mathrm{P})$

f. Analisa nilai erosivitas lahan (Y) metode USLE

\section{Diagram Alir Penelitian}

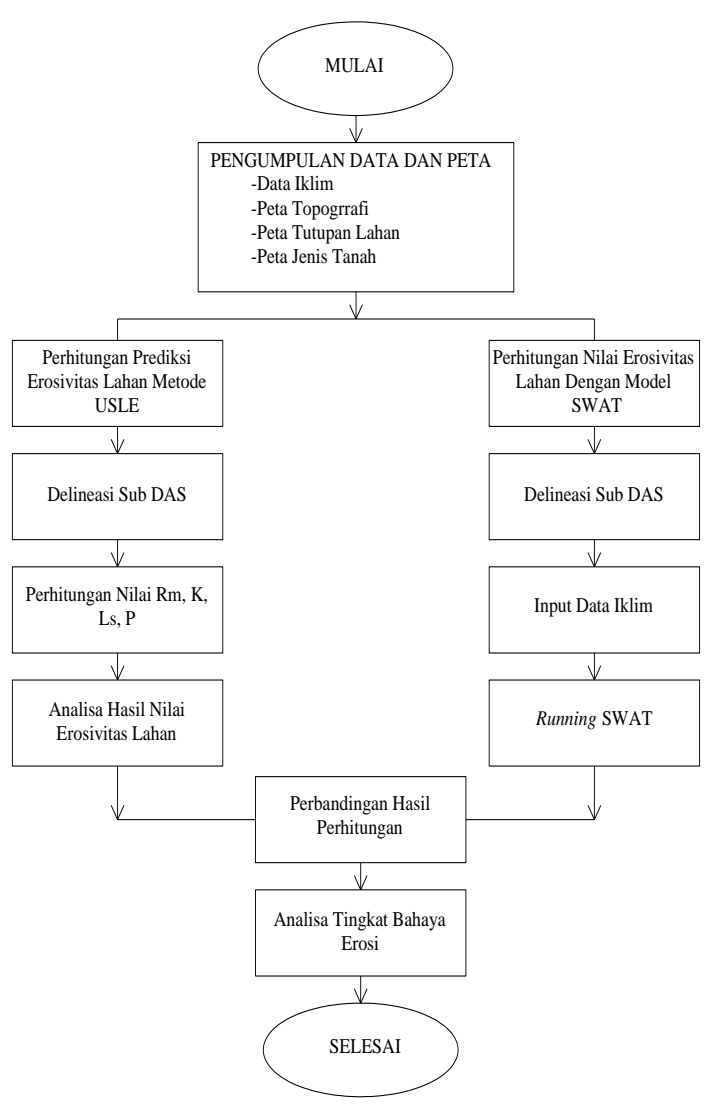

Gambar 2. Diagram Alir Penelitian

\section{HASIL DAN PEMBAHASAN}

\section{Analisa HRU}

Pada analisa HRU, diperoleh kemiringan pada DAS Batang Agam dengan level kemiringan sebagai berikut.

- Agak datar : kemiringan 1-3\%

- Agak landai : kemiringan 3-8\%

- Bergelombang : kemiringan $8-15 \%$

- Berbukit kecil : kemiringan $15-25 \%$

- Agak curam : kemiringan 16-25\%

- Berbukit : kemiringan $25-40 \%$

- Pegunungan : kemiringan $>40 \%$

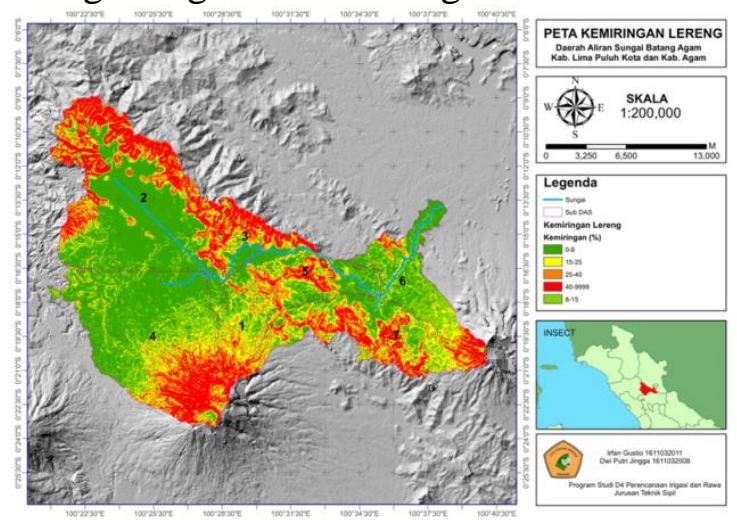

Gambar 3. Peta Kemiringan Lereng DAS Batang Agam

Hasil analisis cluster pada DEM SRTM ini diperoleh 7 sub DAS dengan luas area yang bervariasi. Berdasarkan gambar terlihat bahwa subDAS yang mempunyai luas terbesar adalah subDAS 2 dan yang terkecil adalah subDAS 3 .

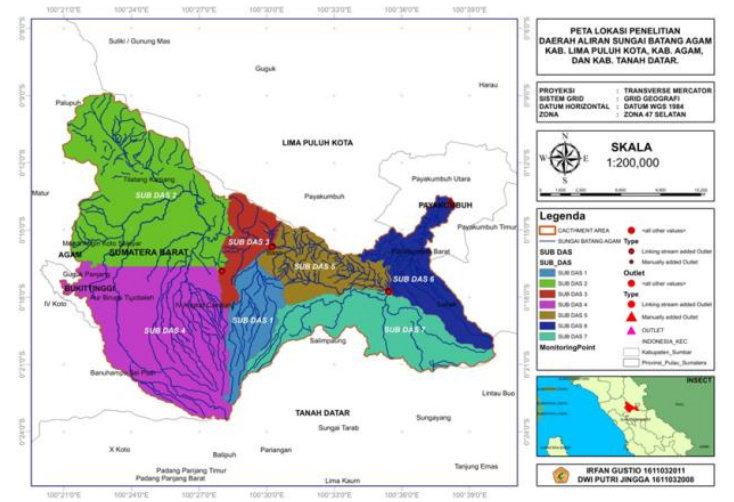

Gambar 4. subDAS yang diperoleh dari analisis cluster berdasarkan DEM SRTM

Klasifikasi Kelas Penggunaan Lahan 
Perubahan Hydrologic Response Unit (HRU) dapat diamati berdasarkan perubahan tutupan lahan, karena HRU merupakan tumpang tindih dari penutup lahan, lereng, dan karakteristik tanah. Perubahan penutup lahan yang terjadi pada suatu wilayah fenomenanya dapat diamati dengan menggunakan citra satelit multi waktu. Selain perubahan penutup lahan secara temporal, jumlah kelas saat klasifikasi juga akan mempengaruhi pola tutupan lahan. Pada penelitian ini digunakan dua tahap klasifikasi penutup lahan di DAS Batang Agam berdasarkan citra Landsat. Pada tahap ini, diperoleh 9 klasifikasi tataguna lahan di tahun 2019 seperti hutan lahan basah primer, pertanian, lahan kering campur semak, semak belukar, padang rumput, rawa, sawah, pemukiman, kebun, dan tanah terbuka. Sedangkan di tahun 2010 dan 2014 terjadi perubahan menjadi 8 klasifikasi tataguna lahan. Yang bertambah pada tahun 2019 adalah rawa.

Tabel 1. Luas Perubahan Tataguna Lahan pada DAS Batang Agam tahun 2010, 2014, dan 2019 Sub DAS 1

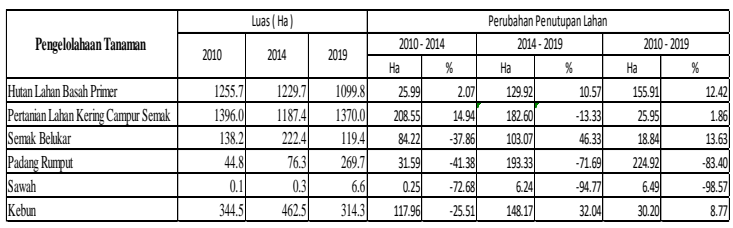

Tabel 2. Luas Perubahan Tataguna Lahan pada DAS Batang Agam tahun 2010, 2014, dan 2019 Sub DAS 2

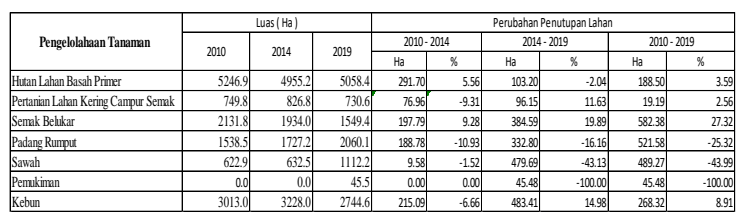

Tabel 3. Perubahan Tataguna Lahan pada DAS Batang Agam tahun 2010, 2014, dan 2019 Sub DAS 3

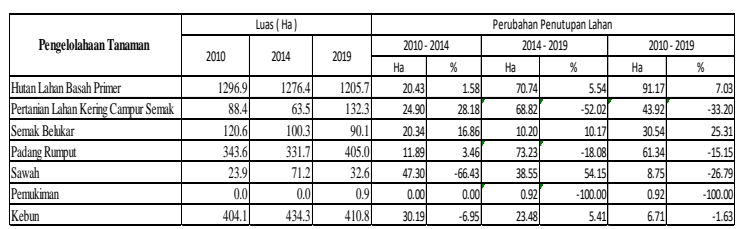

Tabel 4. Perubahan Tataguna Lahan pada DAS Batang Agam tahun 2010, 2014, dan 2019 Sub DAS 4

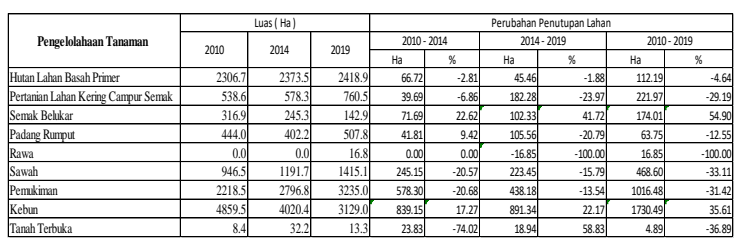

Tabel 5. Perubahan Tataguna Lahan pada DAS Batang Agam tahun 2010, 2014, dan 2019 Sub DAS 5

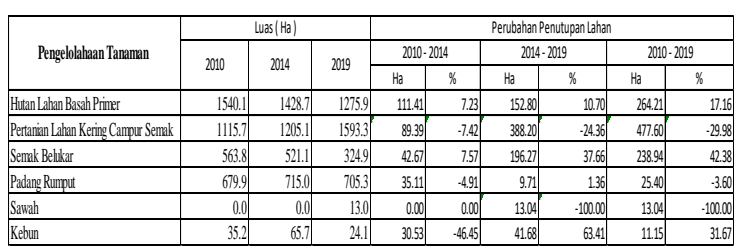

Tabel 6. Perubahan Tataguna Lahan pada DAS Batang Agam tahun 2010, 2014, dan 2019 Sub DAS 6

\begin{tabular}{|c|c|c|c|c|c|c|c|c|c|}
\hline \multirow{3}{*}{ Pengelolahanan Tanamanan } & \multicolumn{3}{|c|}{ Luss(Ha) } & \multicolumn{6}{|c|}{ Pervohahn Penutupan Lhanan } \\
\hline & \multirow{2}{*}{2010} & \multirow{2}{*}{2014} & \multirow{2}{*}{2019} & \multicolumn{2}{|c|}{$2010-2014$} & \multicolumn{2}{|c|}{$2014-2019$} & \multicolumn{2}{|c|}{$2010-2019$} \\
\hline & & & & Ha & $\%$ & Ha & $\%$ & Ha & $\%$ \\
\hline Hutan Latan Basash P.imer & 628.1 & 637.2 & 616.4 & 9.08 & .143 & 20.78 & 3.26 & 11.69 & 1.86 \\
\hline Pertainan Lahan Kering Cannur S Semak & 914.11 & 952.1 & 1222.9 & 38.01 & $.3 .999^{\circ}$ & 270.79 & 28.44 & 38.800 & -25.25 \\
\hline Semak Belkar & 620.9 & 454.9 & 347.2 & 166.95 & 26.73 & 10772 & 23.68 & 273.6 & 4.08 \\
\hline Padang Rumput & 1045.6 & 1230.7 & 987.4 & 185.07 & .15 .94 & 243.35 & 19.77 & 58.28 & 5.57 \\
\hline Sawah & 90.7 & 98.2 & 68.6 & 7.46 & .7 .60 & 29.60 & 30.15 & 22.14 & 24.41 \\
\hline Penmkiman & 148.8 & 173.4 & 205.3 & 24.58 & -44.17 & 3187 & .1838 & 56.45 & .27 .50 \\
\hline Kebun & 666.4 & 568.2 & 666.4 & 98.20 & 14.74 & 98.15 & .17 .27 & 0.05 & 0.01 \\
\hline
\end{tabular}

Tabel 7. Perubahan Tataguna Lahan pada DAS Batang Agam tahun 2010, 2014, dan 2019 Sub DAS 7

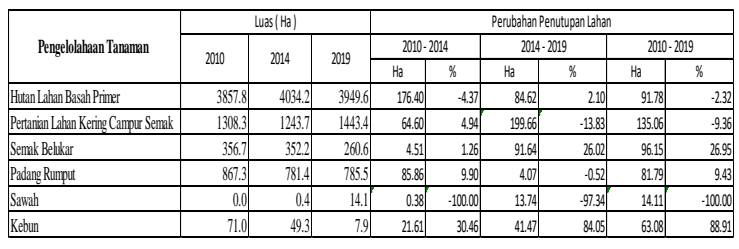

Berdasarkan hasil analisa, data yang diperoleh dari website USGS memiliki 19 klasifikasi. Pada DAS Batang Agam diperoleh klasifikasi perubahan tataguna lahan pada 7 Sub DAS sebanyak 6 sampai 9 klasifikasi yaitu hutan lahan basah primer, pertanian lahan kering campur 
semak, semak berlukar, padang rumput, sawah, kebun, pemukiman, dan rawa. Klasifikasi yang dominan pada DAS Batang Agam adalah hutan lahan basah primer, kebun, dan padang rumput. Subdas 4 merupakan subdas dengan klasifikasi terbanyak yaitu 9 klasifikasi. Subdas 4 didominasi oleh hutan lahan basah primer yang mengalami perubahan sebesar 4,64\% dari tahun 2010 sampai 2019. Pada subdas 4 di tahun 2019 juga mengalami perubahan signifikan pada tahun-tahun sebelumnya yaitu muncul rawa yang terklasifikasikan oleh data citra satelit USGS. Ditinjau dari rata-rata data angka kenaikan pemukiman juga bertambah setiap tahun akan berakibat menambah angka kerusakan pada fungsi lahan pada DAS Batang Agam.

Perubahan tataguna lahan pada tahun 2010, 2014, 2019 ini tidak selalu linier, tetapi berfluktuatif seperti yang terjadi pada pemukiman, sawah, dan pertanian lahan kering campur semak. Untuk hutan lahan kering primer, terjadi kenaikan luas daerah di setiap tahunnya, karena daerah tersebut memang tidak ada terjadi aktivitas manusia. Untuk Pemukiman, terjadi peningkatan luas pada setiap tahun.

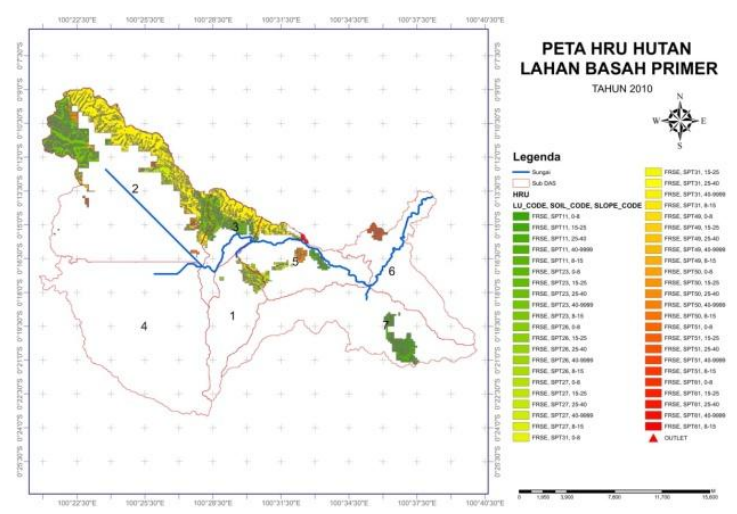

Gambar 5. HRU Hutan Lahan Basah Primer Tahun 2010

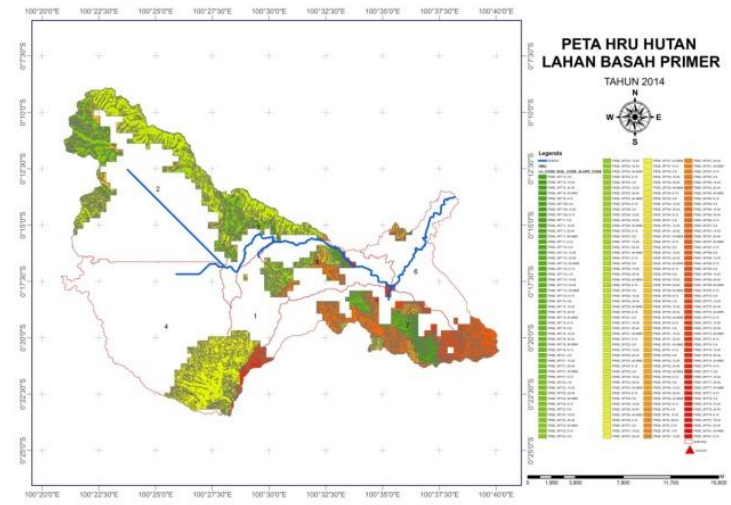

Gambar 6. HRU Hutan Lahan Basah Primer Tahun 2014

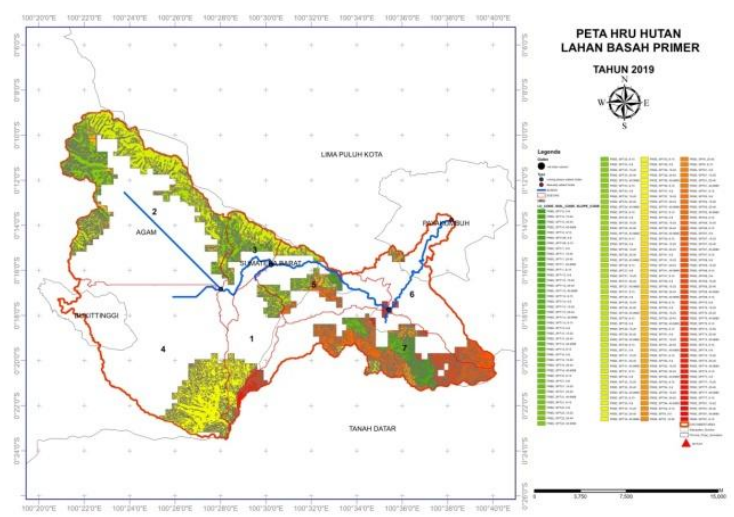

Gambar 7. HRU Hutan Lahan Basah Primer Tahun 2019

Dari tinjauan, hasil HRU Hutan lahan basah primer mengalami kenaikan pada setiap tahun nya. Pada tahun 2010, di subdas 4 dan 1, hutan lahan basah primer terklasifikan. Sementara pada tahun 2014 dan 2019 mengalami pertumbuhan yang mana dapat menjaga kestabilan tanah terhadap erodabilitas.

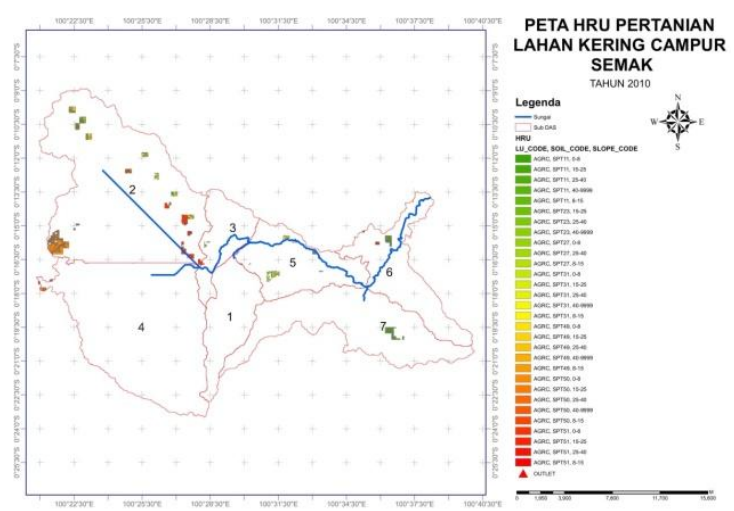

Gambar 8. HRU Pertanian Lahan Kering Campur Semak Tahun 2010 


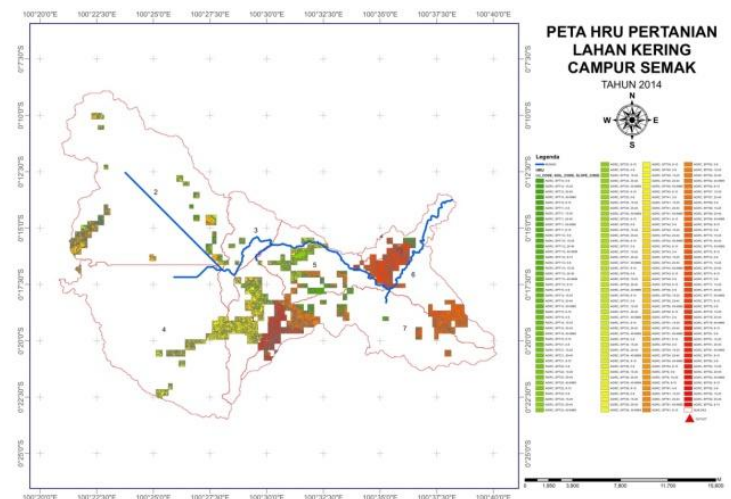

Gambar 9. HRU Pertanian Lahan Kering Campur Semak Tahun 2014

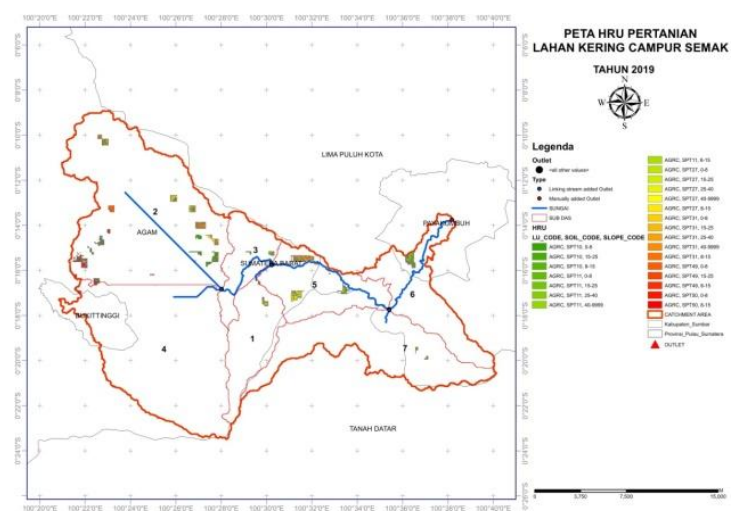

Gambar 10. HRU Pertanian Lahan Kering Campur Semak Tahun 2019

Berdasarkan hasil running aplikasi SWAT, dapat ditinjau jika klasifikasi pertanian lahan kering campuk semak mengalami naik dan turun pada rentang tahun 2010 sampai 2019. Pada tahun 2014 merupakan puncak dari pertumbuhan pertanian lahan kering campur semak .

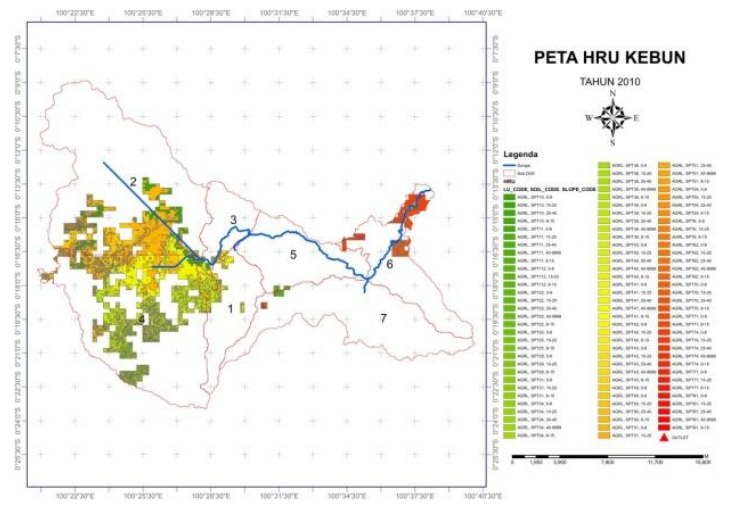

Gambar 11. HRU Kebun Tahun 2010

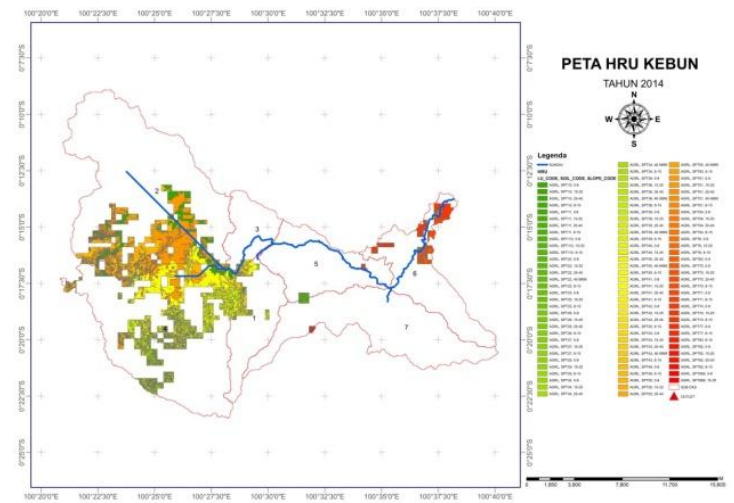

Gambar 12. HRU Kebun Tahun 2014

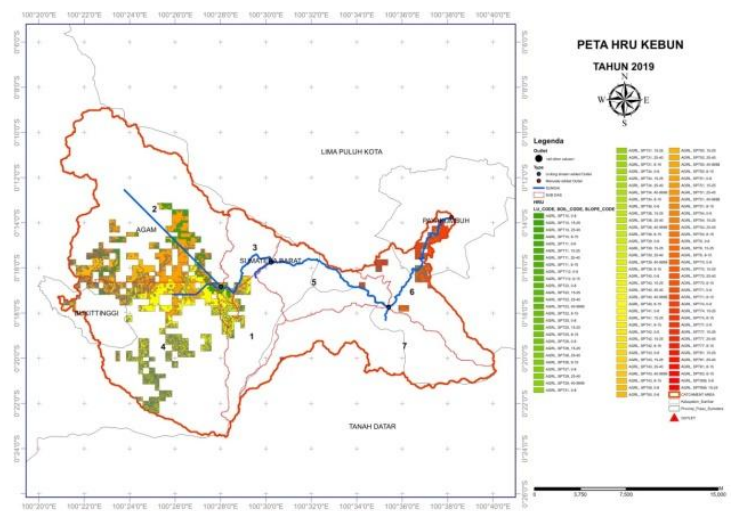

Gambar 13. HRU Kebun Tahun 2019

Ditinjau dari data peta HRU, kebun merupakan klasifikasi yang dominan pada subdas 2 dan 4 . Subdas 2 dan 4 yang berada di kabupaten lima puluh kota ini banyak dimanfaatkan oleh penduduk menjadi lahan kebun. Jika dianalisa dengan angka nilai $\mathrm{C}$, kebun yang tidak dilakukan konservasi pada lahan dapat berdampak pada kenaikan angka erosivitas lahan di DAS Batang Agam.

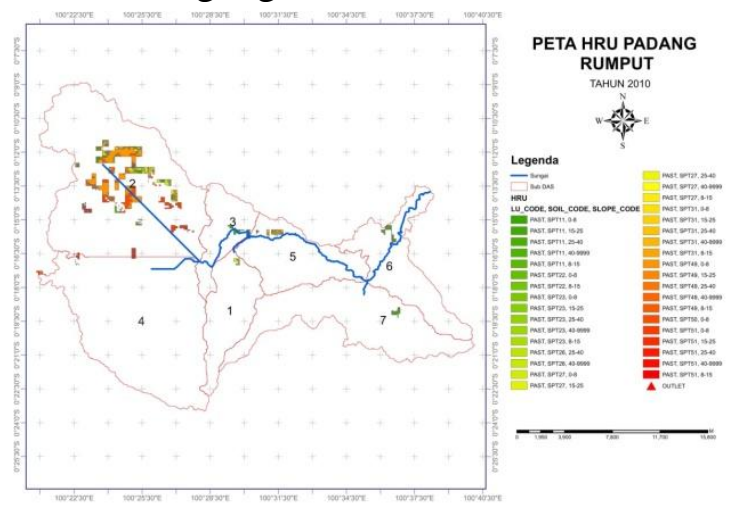

Gambar 14. HRU Padang Rumput Tahun 2010 


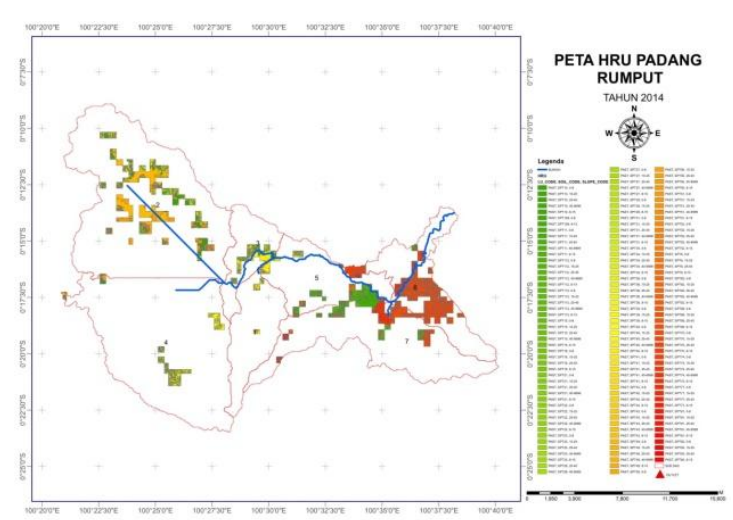

Gambar 15. HRU Padang Rumput Tahun 2014

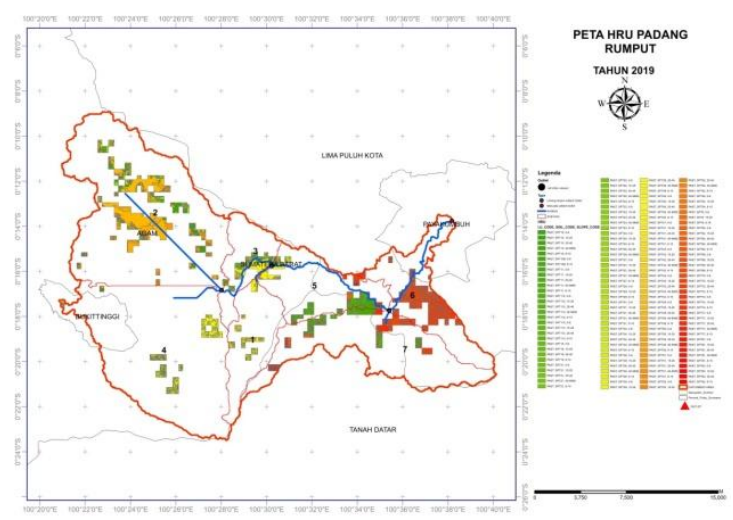

Gambar 16. HRU Padang Rumput Tahun 2019

Dapat ditinjau dari hasil running SWAT, perubahan padang rumput mengalami peningkatan tiap tahunnya, jika ditinjau dari peta tampak sebaran HRU merata di setiap subdas pada setiap tahun.

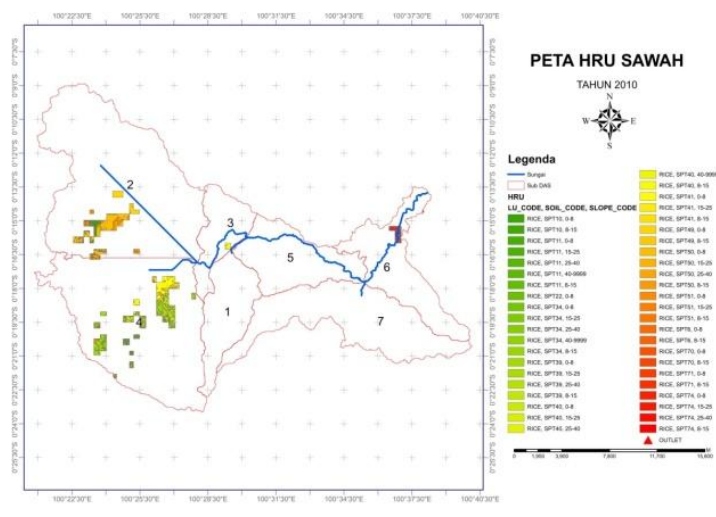

Gambar 17. HRU Sawah Tahun 2010

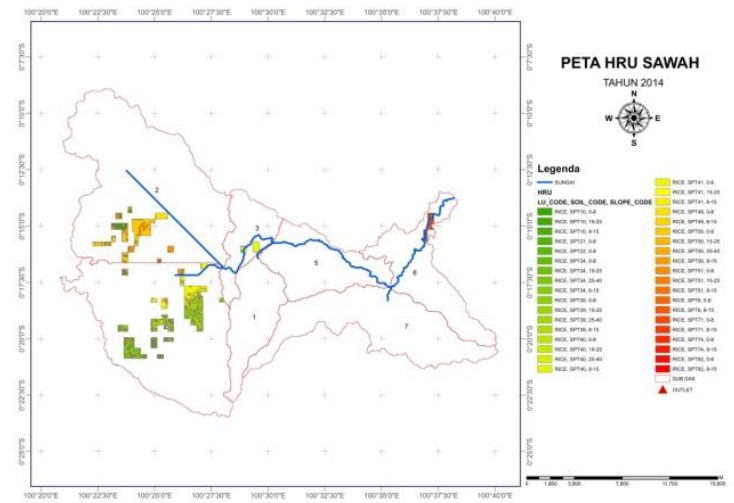

Gambar 18. HRU Sawah Tahun 2014

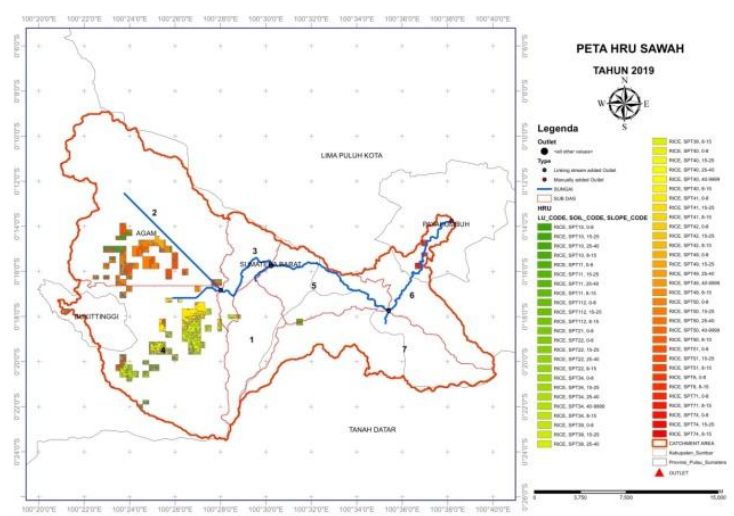

Gambar 19. HRU Sawah Tahun 2019

Menurut hasil proses dari aplikasi, klasifikasi sawah hanya dominan pada subdas 2 dan 4 yang terletak di daerah Agam. Ini disebabkan karena kemiringan lereng lahan pada subdas 1,3,5, dan 7 cukup tinggi.

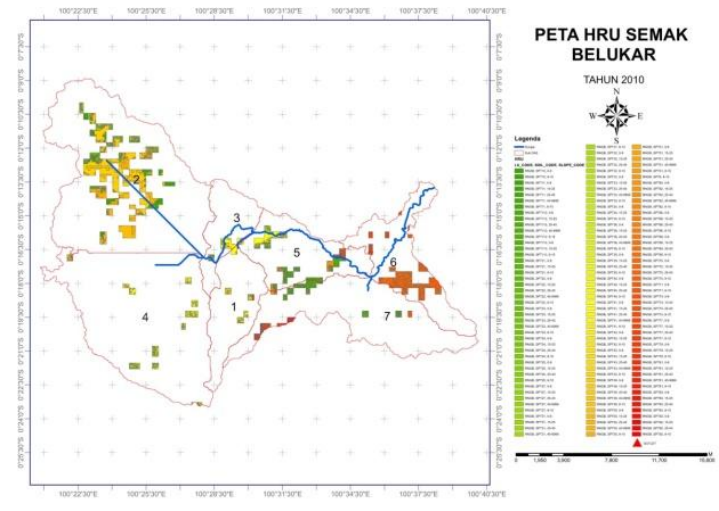

Gambar 20. HRU Semak Belukar Tahun 2010 


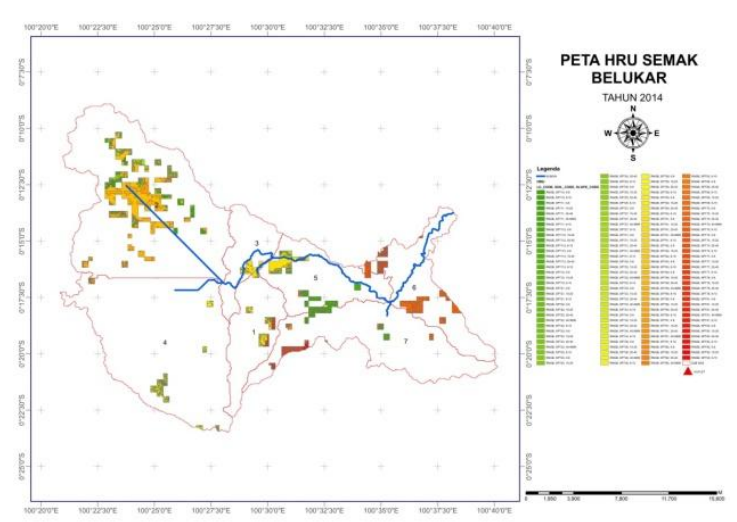

Gambar 21. HRU Semak Belukar Tahun 2014

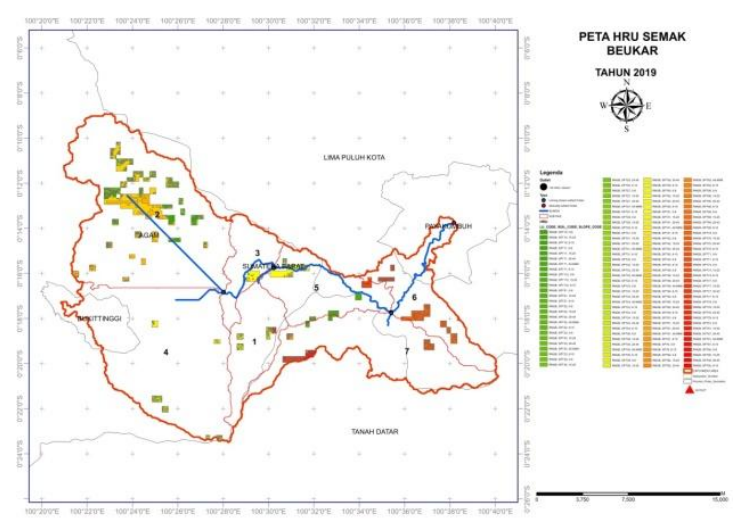

Gambar 22. HRU Semak Belukar Tahun 2019

Dari tinjauan terhadap klasifikasi semak belukar, pertumbuhannya Nampak tidak terlalu siginfikan tiap tahun. Nyaris relatif sama perubahan tiap tahun nya. Subdas 2 merupakan lahan yang paling banyak ditutupi oleh semak berlukar.

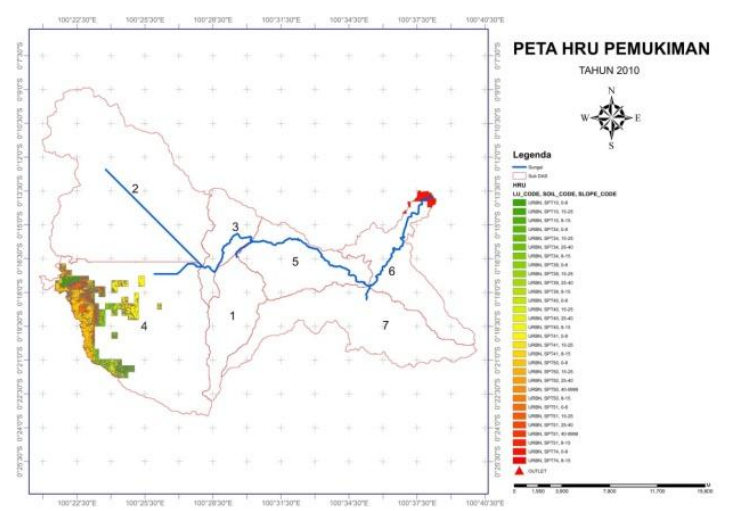

Gambar 23. HRU Pemukiman Tahun 2010

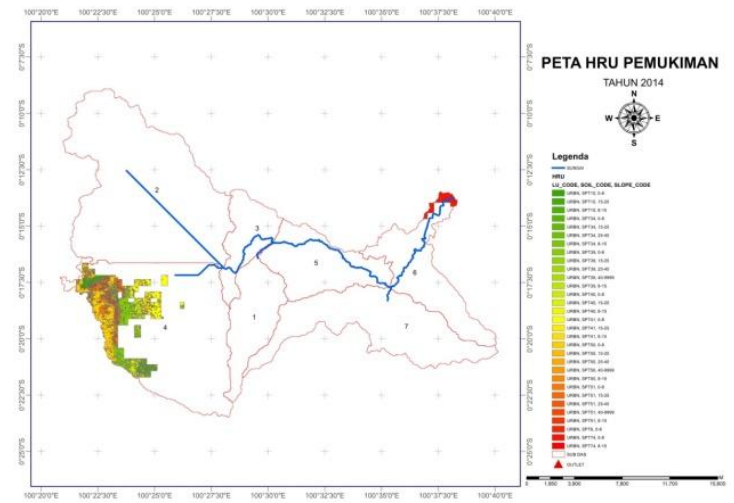

Gambar 24. HRU Pemukiman Tahun 2014
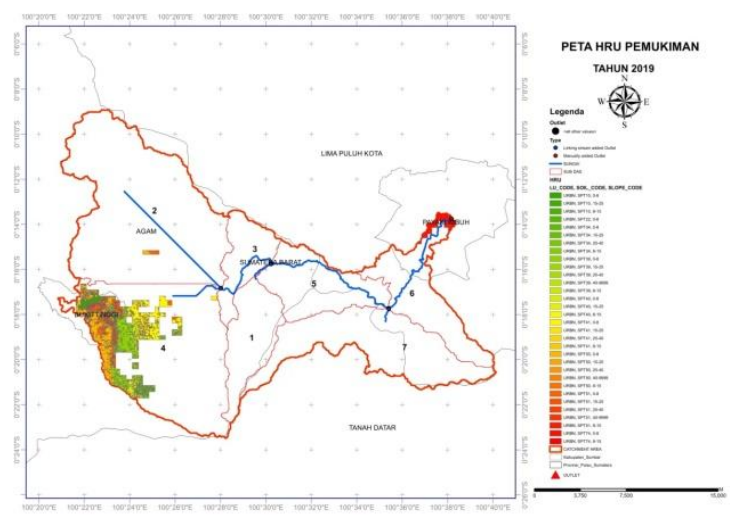

Gambar 25. HRU Pemukiman Tahun 2019

Hasil tinjauan terhadap pemukiman nyaris relatif sama perubahanya tiap tahun. Pemukiman yang diklasifikan oleh tool SWAT hanya di indentifikasi di daerah kota Bukittinggi dan Payakumbuh. Pemukiman merupakan salah satu faktor terbesar yang menyumbang kenaikan angka erosivitas terhadap suatu lahan. Pertumbuhan daerah pemukiman harus sangat dijaga agar dapat menjaga ekosistem DAS.

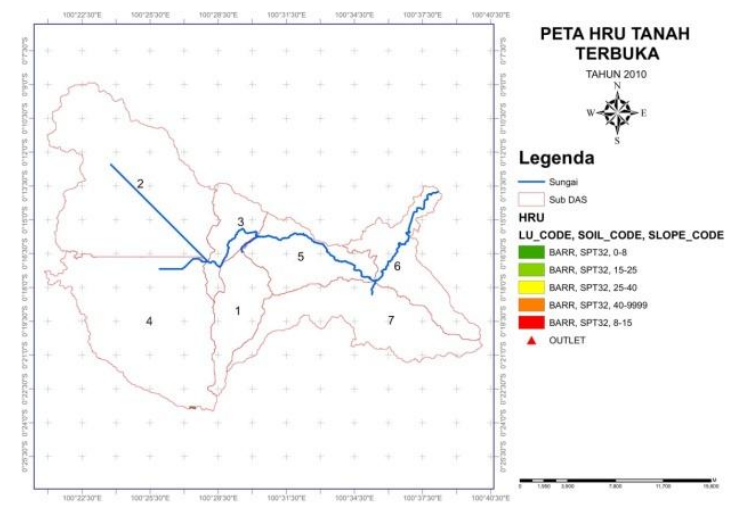

Gambar 26. HRU Tanah Terbuka Tahun 2010 


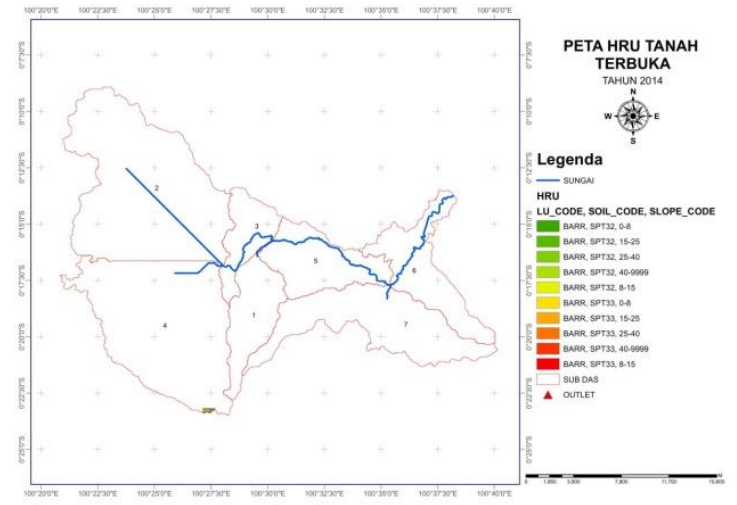

Gambar 27. HRU Tanah Terbuka Tahun 2014

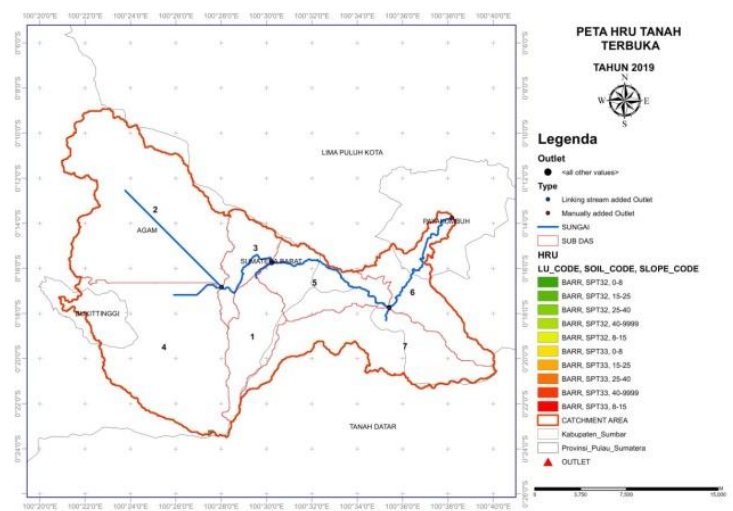

Gambar 28. HRU Tanah Terbuka Tahun 2019

Tanah terbuka dari hasil tinjauan merupakan klasifikasi yang sangat kecil luasannya. Hal ini disebabkan pada DAS Batang Agam yang tingkat tanahnya subur untuk ditumbuhi beraneka tumbuhan dan ekosistem seperti hutan, kebun, semak, dan pertanian.

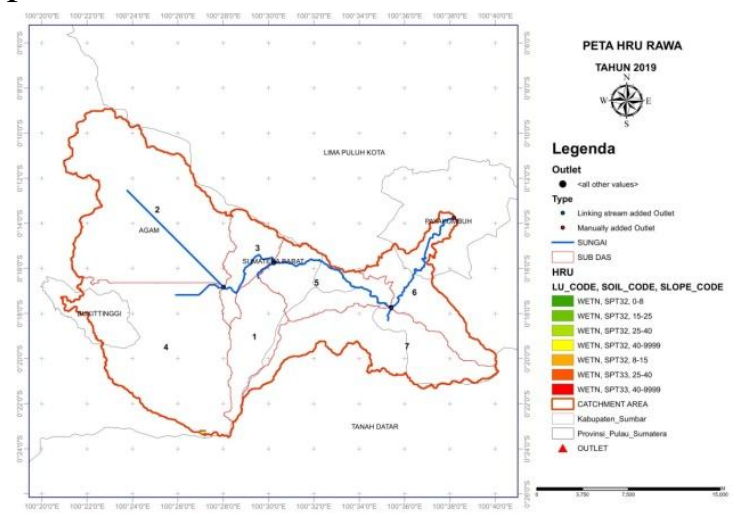

Gambar 29. HRU Rawa Tahun 2019

Dari tinjauan digitasi menampilan klasifikasi rawa yang hanya muncul di tahun 2019 dengan angka yang sangat kecil.

Analisis HRU dibagi berdasarkan penutup lahan yang digunkanan. Hal ini dilakukan agar dapat dilihat pengaruh perubahan lahan terhadap perubahan yang terjadi pada HRU. HRU dapat menganalisa kemiringan, jenis tanah, dan lahan yang ada pada suatu DAS yang ditinjau.

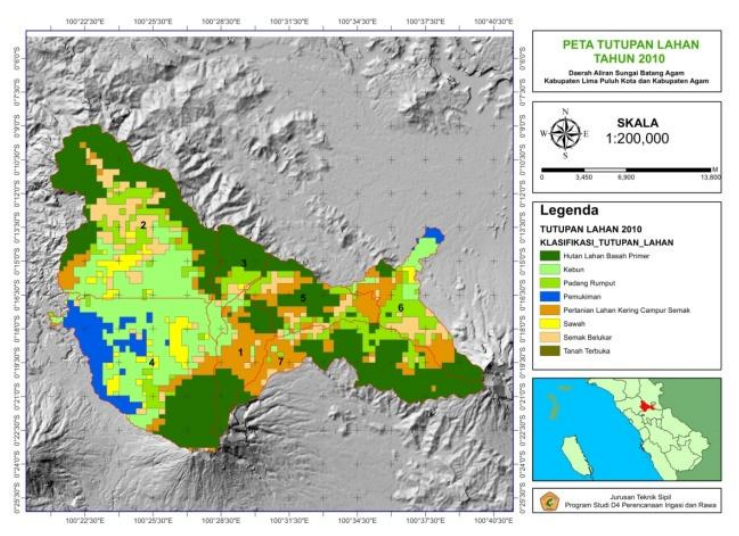

Gambar 30. HRU Penggunaan Lahan Pada Tahun 2010

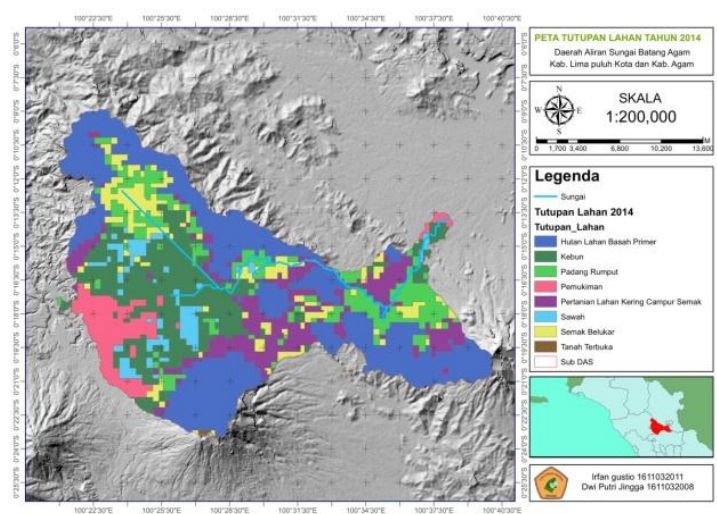

Gambar 31. HRU Penggunaan Lahan Pada Tahun 2014

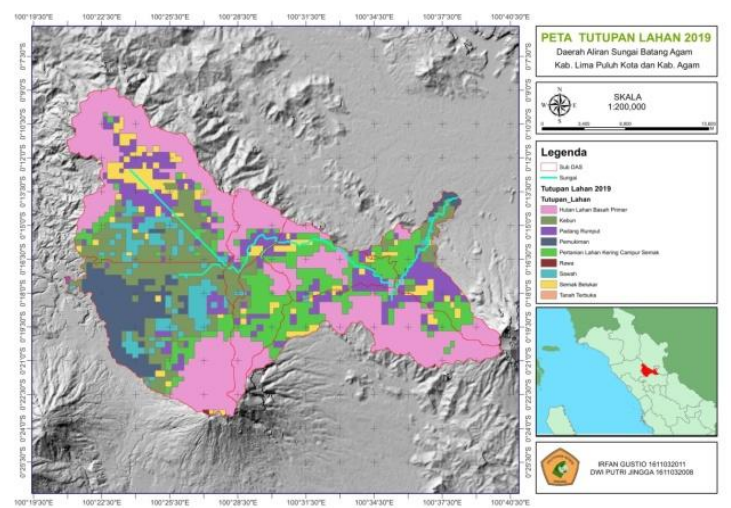

Gambar 32. HRU Penggunaan Lahan Pada Tahun 2019 
Tabel 8. Jumlah HRU pada masing-masing subDAS tahun 2010-2019 di DAS Batang Agam

\begin{tabular}{|c|c|c|c|c|c|c|c|c|c|}
\hline \multirow{2}{*}{ Sub DAS } & \multicolumn{3}{|c|}{ Jumlah HRU } & \multicolumn{3}{|c|}{ HRU Dominan (Jutupan Lahan, Tanah, Kemiringan) } & \multicolumn{3}{|c|}{ Luas HRU Dominan (Ha) } \\
\hline & 2010 & 2014 & 2019 & 2010 & 2014 & 2019 & 2010 & 2014 & 2019 \\
\hline 1 & 181 & 206 & 192 & FRSE/SPT33/40-9999 & FRSE/SPT33/40-9999 & ERSE/SPT33/40-9999 & 166.233 & 166.233 & 166.233 \\
\hline 2 & 264 & 256 & 284 & FRSE/SPT31/40-9999 & FRSE/SPT31/40-9999 & ERSE/SPT31/40-9999 & 1458.13 & 1427.4 & 1453.9 \\
\hline 3 & 132 & 126 & 130 & FRSE/SPT31/40-9999 & FRSE/SPT31/40-9999 & ERSE/SPT31/40-9999 & 383.867 & 382.74 & 381.236 \\
\hline 4 & 219 & 215 & 226 & FRSE/SPT33/40-9999 & FRSE/SPT33/40-9999 & ERSE/SPT33/40-9999 & 1140.23 & \begin{tabular}{|l|l|}
1143.8 \\
\end{tabular} & 1141.73 \\
\hline 5 & 222 & 211 & 200 & FRSE/SPT62/40-9999 & RNGB/SPT41/0-8 & PAST/SPT112/0-8 & 158.527 & 183.054 & 169.334 \\
\hline 6 & 158 & 149 & 150 & PAST/SPT70/8-15 & PAST/SPT70/8-15 & PAST/SPT70/8-15 & 385.559 & 509.505 & 450.68 \\
\hline 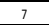 & 227 & 232 & 229 & FRSE/SPT62/25-40 & FRSE/SPT62/25-40 & FRSE/SPT62/25-40 & 512.23 & 510.445 & 524.822 \\
\hline
\end{tabular}

Berdasarkan tabel di atas, dapat kita lihat bahwa HRU pada setiap subDAS mengalami naik turun yang tidak jauh, ini mengindikasikan bahwa tidak terjadi perubahan yang signifikan di setiap subDAS Batang Agam. Hal ini terkait dengan perubahan tataguna lahan yang terjadi, yang mengakibatkan perubahan pola spasial HRU di wilayah tersebut. Berubahnya pola spasial tersebut juga menyebabkan berubahnya HRU dominan dan luasnya. Namun pada subDAS 5 terjadi penurunan jumlah HRU dari tahun 2010 hingga 2019, jika ditinjau dari lokasi, subDAS tersebut berada di kecamatan Baso yang di dominasi oleh hutan dan semak. Disini dapat dianalisa bahwa terjadi banyak perubahan pengalihan lahan di subDAS tersebut.

\section{Perhitungan Cara Manual Erosi Metode USLE}

1. Faktor Erosivitas Hujan (R)

$\mathrm{RM}=6,119 \times($ Rain $) \mathrm{cm}^{1,21} \times($ Dayas $) \mathrm{cm}^{-}$ ${ }^{0,47} \mathrm{x}(\operatorname{Max} \mathrm{P}) \mathrm{cm}^{0,53}$

Tabel 9. Indeks Erosivitas (R) STA. Canduang

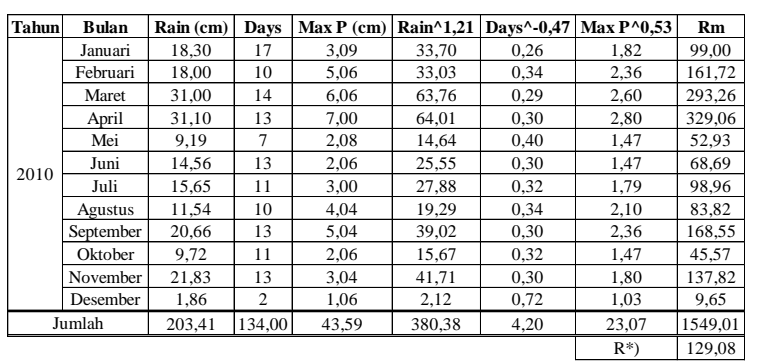

Tabel 10. Indeks Erosivitas (R) STA. Tanjuang Pati

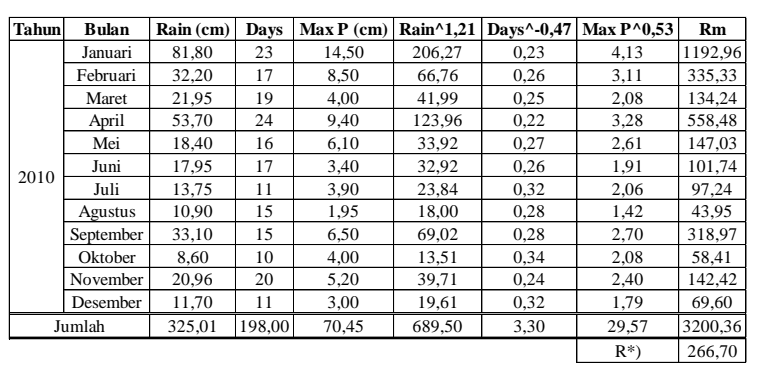

Tabel 11. Indeks Erosivitas (R) STA. Suliki

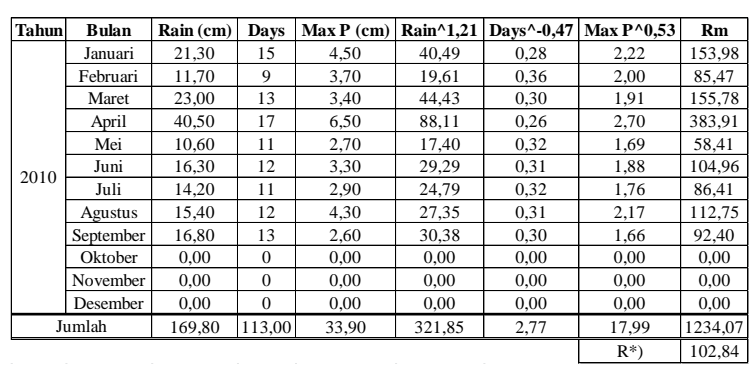

2. Faktor Erodibilitas Tanah (K)

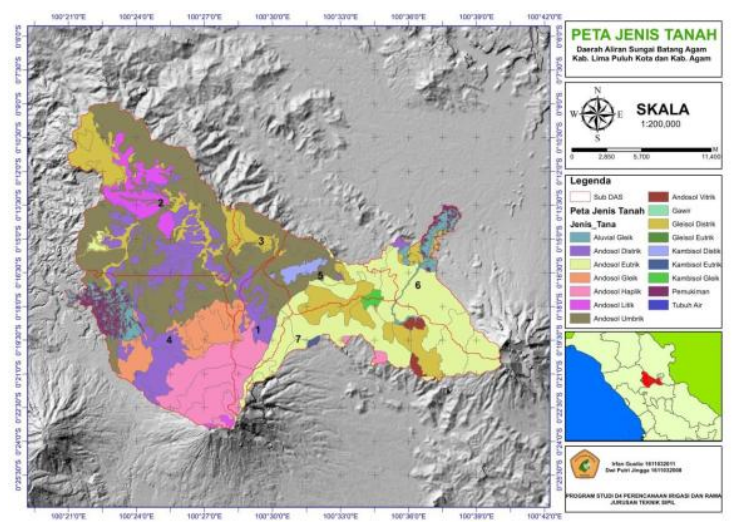

Gambar 33. Peta Jenis Tanah

Tabel 12. Nilai Faktor Erodibilitas Tanah (K)

\begin{tabular}{|c|c|c|c|}
\hline NO & Sub Das & Luas $(\mathrm{km} 2)$ & Nilai K \\
\hline 1 & 1 & 3178,90 & 0,16 \\
\hline 2 & 2 & 13300,33 & 0,17 \\
\hline 3 & 3 & 2278,25 & 0,18 \\
\hline 4 & 4 & 11643,93 & 0,20 \\
\hline 5 & 5 & 3936,15 & 0,15 \\
\hline 6 & 6 & 4116,38 & 0,19 \\
\hline 7 & 7 & 6462,38 & 0,17 \\
\hline
\end{tabular}

3. Faktor Panjang dan Kemiringan Kelerengan (LS) 


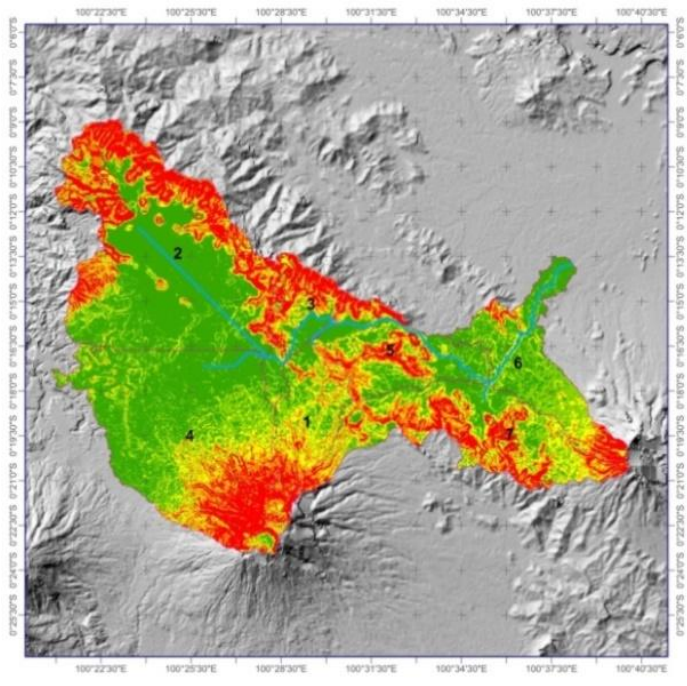

Gambar 34. Peta Kemiringan Lereng

Tabel 13. Indeks Panjang dan Kemiringan Lereng

\begin{tabular}{|c|c|c|c|}
\hline NO & Sub Das & Luas $(\mathrm{km} 2)$ & Nilai Ls \\
\hline 1 & 1 & 3178,90 & 2,34 \\
\hline 2 & 2 & 13300,33 & 2,60 \\
\hline 3 & 3 & 2278,25 & 3,11 \\
\hline 4 & 4 & 11643,93 & 1,99 \\
\hline 5 & 5 & 3936,15 & 2,20 \\
\hline 6 & 6 & 4116,38 & 1,38 \\
\hline 7 & 7 & 6462,38 & 2,73 \\
\hline
\end{tabular}

4. Faktor Pengelolaan Tanaman (C)

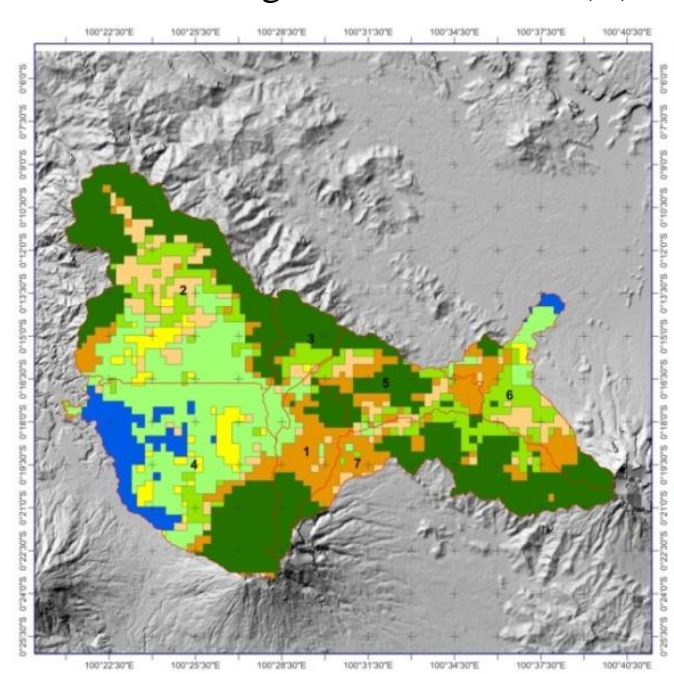

Gambar 35. Peta Tutpan Lahan 2010
Tabel 14. Nilai Vegetasi Penutupan Lahan dan Pengelolaan Tanaman pada tahun 2010

\begin{tabular}{|c|c|c|c|}
\hline NO & Sub Das & Luas $(\mathrm{km} 2)$ & Nilai C \\
\hline 1 & 1 & 3178,90 & 0,02 \\
\hline 2 & 2 & 13300,33 & 0,08 \\
\hline 3 & 3 & 2278,25 & 0,04 \\
\hline 4 & 4 & 11643,93 & 0,09 \\
\hline 5 & 5 & 3936,15 & 0,09 \\
\hline 6 & 6 & 4116,38 & 0,12 \\
\hline 7 & 7 & 6462,38 & 0,05 \\
\hline \hline
\end{tabular}

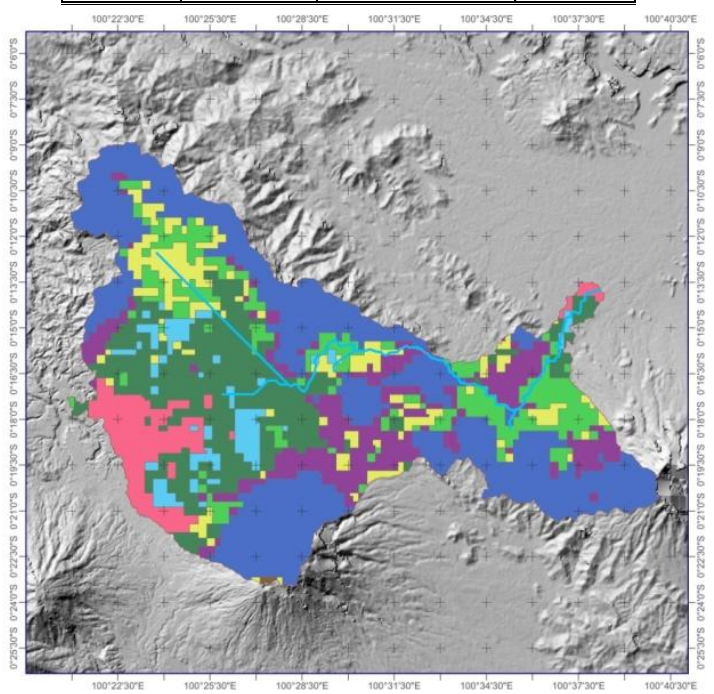

Gambar 36 Peta Tutupan Lahan 2014

Tabel 15 Nilai Vegetasi Penutupan Lahan dan Pengelolaan Tanaman pada tahun 2014

\begin{tabular}{|c|c|c|c|}
\hline NO & Sub Das & Luas $(\mathrm{km} 2)$ & Nilai C \\
\hline 1 & 1 & 3178,90 & 0,04 \\
\hline 2 & 2 & 13300,33 & 0,08 \\
\hline 3 & 3 & 2278,25 & 0,05 \\
\hline 4 & 4 & 11643,93 & 0,10 \\
\hline 5 & 5 & 3936,15 & 0,03 \\
\hline 6 & 6 & 4116,38 & 0,13 \\
\hline 7 & 7 & 6462,38 & 0,05 \\
\hline
\end{tabular}




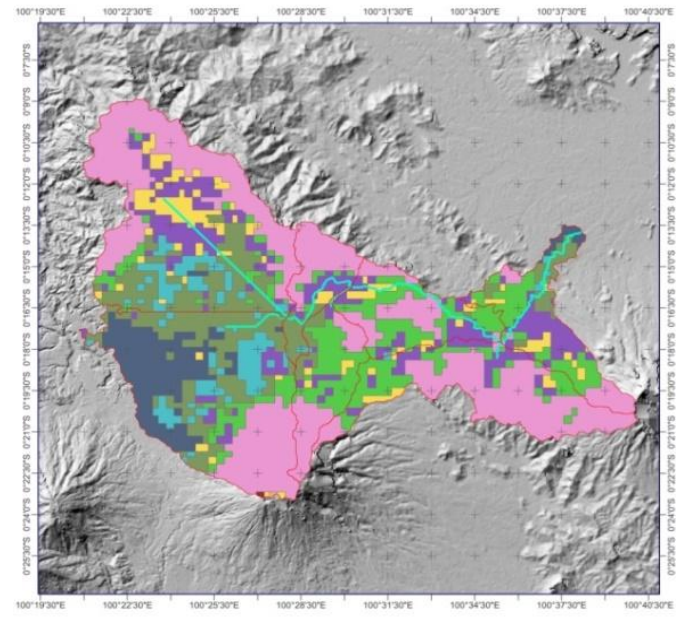

Gambar 37. Peta Tutupan Lahan 2019

Tabel 16. Nilai Vegetasi Penutupan Lahan dan Pengelolaan Tanaman pada tahun 2019

\begin{tabular}{|c|c|c|c|}
\hline NO & Sub Das & Luas $(\mathrm{km} 2)$ & Nilai C \\
\hline 1 & 1 & 3178,90 & 0,05 \\
\hline 2 & 2 & 13300,33 & 0,08 \\
\hline 3 & 3 & 2278,25 & 0,06 \\
\hline 4 & 4 & 11643,93 & 0,11 \\
\hline 5 & 5 & 3936,15 & 0,08 \\
\hline 6 & 6 & 4116,38 & 0,11 \\
\hline 7 & 7 & 6462,38 & 0,05 \\
\hline
\end{tabular}

5. Faktor Tindakan Konservasi Tanah (P) Faktor tindakan-tindakan khusus konservasi tanah $(\mathrm{P})$ yaitu nisbah antara besarnya erosi dari tanah yang diberi perlakuan tindakan konservasi khusus seperti pengolahan tanah menurut kontur, penanaman dalam strip atau teras terhadap besarnya erosi dari tanah yang diolah searah lereng dalam keadaan yang identik. Pada perhitungan ini digunakan nilai 1 karena keadaan lahan yang dianggap tidak ada konservasi.

6. Hasil perhitungan erosivitas lahan dengan metode USLE

Tabel 17. Hasil Perhitungan Erosi dengan Metode USLE Tahun 2010

\begin{tabular}{|c|c|c|c|c|c|c|c|c|}
\hline No & Sub Das & Luas (km2) & Rm & K & Ls & C & P & A (Ton/Ha/Tahun) \\
\hline 1 & 1 & 3178,90 & 129,08 & 0,161 & 2,34 & 0,02 & 1,00 & 1,19 \\
\hline 2 & 2 & 13300,33 & 123,71 & 0,17 & 2,60 & 0,08 & 1,00 & 4,29 \\
\hline 3 & 3 & 2278,25 & 129,08 & 0,18 & 3,11 & 0,04 & 1,00 & 3,10 \\
\hline 4 & 4 & 11643,93 & 129,08 & 0,20 & 1,99 & 0,09 & 1,00 & 4,40 \\
\hline 5 & 5 & 3936,15 & 129,08 & 0,15 & 2,20 & 0,09 & 1,00 & 3,87 \\
\hline 6 & 6 & 4116,38 & 240,93 & 0,19 & 1,38 & 0,12 & 1,00 & 7,97 \\
\hline 7 & 7 & 6462,38 & 139,80 & 0,17 & 2,73 & 0,05 & 1,00 & 3,58 \\
\hline \multicolumn{7}{|c|}{ Total } \\
\hline
\end{tabular}

Tabel 18. Hasil Perhitungan Erosi dengan Metode USLE Tahun 2014

\begin{tabular}{|c|c|c|c|c|c|c|c|c|}
\hline No & Sub Das & Luas $(\mathbf{k m 2})$ & Rm & K & Ls & $\mathbf{C}$ & $\mathbf{P}$ & $\mathbf{A}($ Ton/Ha/Tahun) \\
\hline 1 & 1 & 3178,90 & 128,75 & 0,16 & 2,34 & 0,04 & 1,00 & 1,84 \\
\hline 2 & 2 & 13300,33 & 126,80 & 0,17 & 2,60 & 0,08 & 1,00 & 4,41 \\
\hline 3 & 3 & 2278,25 & 128,75 & 0,18 & 3,11 & 0,05 & 1,00 & 3,83 \\
\hline 4 & 4 & 11643,93 & 128,75 & 0,20 & 1,99 & 0,10 & 1,00 & 5,02 \\
\hline 5 & 5 & 3936,15 & 128,75 & 0,15 & 2,20 & 0,03 & 1,00 & 1,32 \\
\hline 6 & 6 & 4116,38 & 130,62 & 0,19 & 1,38 & 0,13 & 1,00 & 4,42 \\
\hline 7 & 7 & 6462,38 & 128,93 & 0,17 & 2,73 & 0,05 & 1,00 & 3,07 \\
\hline \multicolumn{7}{|c|}{ Total } \\
\hline
\end{tabular}

Tabel 19. Hasil Perhitungan Erosi dengan Metode USLE Tahun 2019

\begin{tabular}{|c|c|c|c|c|c|c|c|c|}
\hline No & Sub Das & Luas (km2) & Rm & K & Ls & C & P & A (Ton/Ha/Tahun) \\
\hline 1 & 1 & 3178,90 & 102,75 & 0,16 & 2,34 & 0,05 & 1,00 & 1,78 \\
\hline 2 & 2 & 13300,33 & 104,49 & 0,17 & 2,60 & 0,08 & 1,00 & 3,68 \\
\hline 3 & 3 & 2278,25 & 102,75 & 0,18 & 3,11 & 0,06 & 1,00 & 3,45 \\
\hline 4 & 4 & 11643,93 & 102,75 & 0,20 & 1,99 & 0,11 & 1,00 & 4,36 \\
\hline 5 & 5 & 3936,15 & 102,75 & 0,15 & 2,20 & 0,08 & 1,00 & 2,73 \\
\hline 6 & 6 & 4116,38 & 158,43 & 0,19 & 1,38 & 0,11 & 1,00 & 4,73 \\
\hline 7 & 7 & 6462,38 & 108,09 & 0,17 & 2,73 & 0,05 & 1,00 & 2,44 \\
\hline \multicolumn{1}{|c|}{ Total } \\
\hline \multicolumn{19}{|c|}{} \\
\hline
\end{tabular}

Tabel 20. Grafik Simulasi Erosi metode USLE

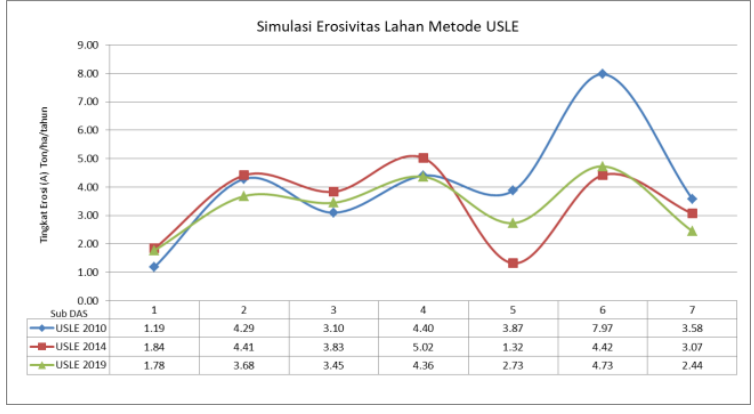

Berdasarkan hasil perhitungan yang ada di grafik, dapat dianalisa jika nilai erosi lahan yang terjadi di setiap das tidak terlalu besar. Rata-rata di setiap subDAS, Hutan lahan basah primer merupakan klasifikasi yang dominan diantara tutupan lahan lainnya. Hal ini dapat dilihat pada perhitungan nilai $\mathrm{C}$ dan di peta tutupan lahan. Nilai erosi terbesar terjadi pada tahun 2010 di subDAS 6. SubDAS berada pada wilayah kota payakumbuh, di subDAS 6 di dominasi oleh pertanian lahan kering campur semak, padang rumput dan pemukiman. Sementara nilai erosi terendah terjadi pada tahun 2010 di subDAS 1 . Dimana subDAS 1 di dominasi oleh hutan lahan basah primer. Sementara itu subDAS 4 dan 6 merupakan penyumbangan angka terbesar untuk nilai erosi di outlet bendung Batang Agam.

\section{Analisis Erosivitas Lahan}

Setelah dilakukan perhitungan USLE secara manual dan hasil simulasi 
permodelan SWAT, dapat kita peroleh grafik USLE sebagai berikut :

Tabel 21. Grafik perbandingan simulasi Erosi Metode USLE dan SWAT pada tahun 2010

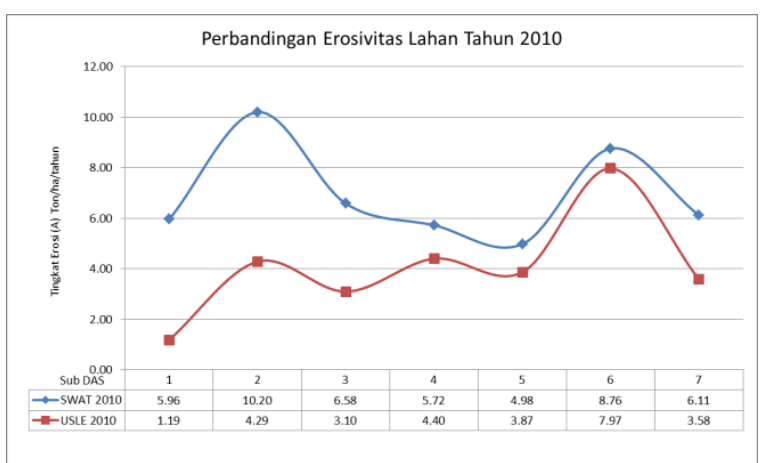

Dapat dianalisa dari grafik jika kecenderungan antara grafik hasil perhitungan erosi SWAT dengan USLE hampir sama. Dimana nilai terbesar pada SWAT ada di subDAS 2, sementara pada USLE ada di subDAS 6.

Tabel 22. Grafik perbandingan simulasi Erosi Metode USLE dan SWAT pada tahun 2014

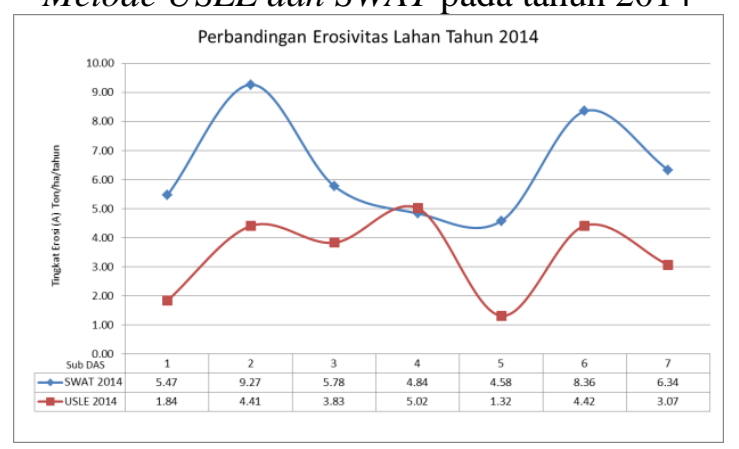

Dari hasil perhitungan di tahun 2014 didapatkan kecenderungan grafik yang hampir sama, namun posisi nilai erosi terbesar di subDAS yang berbeda antara perhitungan SWAT dengan USLE. Pada perhitungan SWAT nilai terbesar berada di subDAS dengan angka 9,27 ton/ha. Sementara perhitungan USLE, nilai terbesar berada di subDAS 4 dengan besaran nilai 5,02 ton/ha.
Tabel 23. Grafik perbandingan simulasi Erosi Metode USLE dan SWAT pada tahun 2019

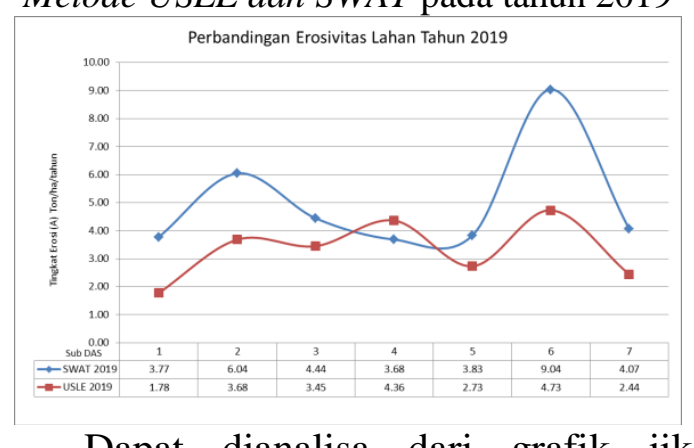
kecenderungan antara grafik hasil perhitungan erosi SWAT dengan USLE hampir sama. Dimana nilai terbesar pada SWAT ada di subDAS 6, sementara pada USLE ada di subDAS 6.

Tabel 24. Grafik Total Nilai Erosi pada Outlet Perbandingan SWAT dengan USLE

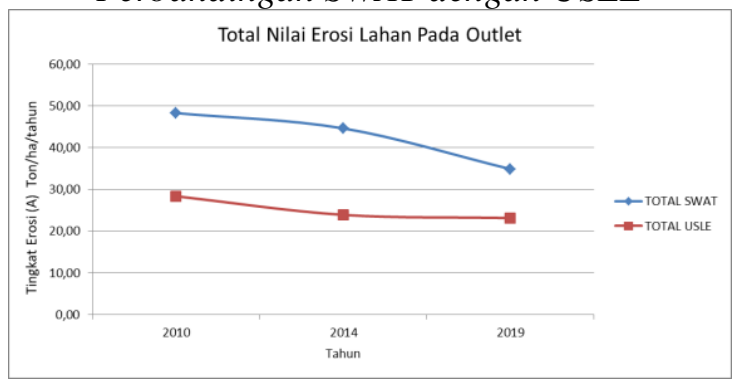

Dari grafik total nilai erosi lahan pada outlet antara USLE dengan SWAT, didapatkan kecenderungan nilai yang mengalami penurunan tiap tahun nya, hal ini didukung dengan pertumbuhan hutan lahan basah primer dan semak belukar yang persentase nya naik tiap tahun. Hutan lahan basah kering merupakan klasifikasi yang dapat menurunkan besaran angka erosi. Sementara untuk klasifikasi pemukiman tidak mengalami perubahan yang terlalu signifikan. Dengan hal tersebut sangat mendukung penurunan nilai erosi yang terjadi di DAS Batang Agam. 
Tabel 25. Klasifikasi Tingkat Bahaya Erosi Tahun 2010

\begin{tabular}{|c|c|c|c|}
\hline Sub DAS & Laju Erosi (Ton/ha/tahun) & $\begin{array}{c}\text { Interval Klasifikasi } \\
\text { Laju Erosi (Ton/ha/tahun) }\end{array}$ & Keterangan \\
\hline 1 & 1,19 & $<15$ & Sangat Ringan \\
\hline 2 & 4,29 & $<15$ & Sangat Ringan \\
\hline 3 & 3,10 & $<15$ & Sangat Ringan \\
\hline 4 & 4,40 & $<15$ & Sangat Ringan \\
\hline 5 & 3,87 & $<15$ & Sangat Ringan \\
\hline 6 & 7,97 & $<15$ & Sangat Ringan \\
\hline 7 & 3,58 & $<15$ & Sangat Ringan \\
\hline
\end{tabular}

Tabel 26. Klasifikasi Tingkat Bahaya Erosi Tahun 2014

\begin{tabular}{|c|c|c|c|}
\hline Sub DAS & Laju Erosi (Ton/ha/tahun) & $\begin{array}{c}\text { Interval Klasifikasi } \\
\text { Laju Erosi (Ton/ha/tahun) }\end{array}$ & Keterangan \\
\hline 1 & 1,84 & $<15$ & Sangat Ringan \\
\hline 2 & 4,41 & $<15$ & Sangat Ringan \\
\hline 3 & 3,83 & $<15$ & Sangat Ringan \\
\hline 4 & 5,02 & $<15$ & Sangat Ringan \\
\hline 5 & 1,32 & $<15$ & Sangat Ringan \\
\hline 6 & 4,42 & $<15$ & Sangat Ringan \\
\hline 7 & 3,07 & $<15$ & Sangat Ringan \\
\hline
\end{tabular}

Tabel 27. Klasifikasi Tingkat Bahaya Erosi Tahun 2019

\begin{tabular}{|c|c|c|c|}
\hline Sub DAS & Laju Erosi (Ton/ha/tahun) & $\begin{array}{c}\text { Interval Klasifikasi } \\
\text { Laju Erosi (Ton/ha/tahun) }\end{array}$ & Keterangan \\
\hline 1 & 1,78 & $<15$ & Sangat Ringan \\
\hline 2 & 3,68 & $<15$ & Sangat Ringan \\
\hline 3 & 3,45 & $<15$ & Sangat Ringan \\
\hline 4 & 4,36 & $<15$ & Sangat Ringan \\
\hline 5 & 2,73 & $<15$ & Sangat Ringan \\
\hline 6 & 4,73 & $<15$ & Sangat Ringan \\
\hline 7 & 2,44 & $<15$ & Sangat Ringan \\
\hline
\end{tabular}

Dari hasil 3 tahun klasifikasi interval laju erosi didapat angka yang kecil dalam interval kelas bahaya erosi, dimana nilai berada dalam rentang 3,68 sampai 10,20 yang di klasifikasi sebagai tingkat bahaya yang sangat ringan ( $<15$ ton/ha/tahun). Sementara untuk hasil total nilai erosi di outlet sendiri mengeluarkan angka dalam rentang 48,31 sampai 34,88 yang dikategorikan sebagai tingkat bahaya erosi kelas ringan. SubDAS 6 menjadi penyumbang nilai erosi terbesar dibandingkan subDAS lainnya dengan besaran 8,36 sampai 9,04 ton/ha/tahun. Sementara subDAS 4 menjadi penyumbang nilai erosi paling kecil dengan rentang angka 3,68 sampai 4,84.

\section{SIMPULAN}

a. Pada analisa unit respon hidrologi (HRU), untuk tanah pada DAS Batang Agam didominasi oleh kedalaman tanah (solum) mencakup horizon A dan B. Itu artinya bahwa kapasitas penyimpanan air pada tanah DAS tersebut mempunyai kapasitas sangat dalam. Untuk kemiringan DAS, pada daerah hulu DAS terdapat pegunungan dengan kemiringan $>40 \%$. Pada tahun 20102019, perubahan jumlah dan luas HRU mempengaruhi akumulasi aliran permukaan, erosivitas lahan dan debit andalan secara temporal. Hal ini disebabkan oleh koefisien runoff yang menurun akibat perubahan penggunaan lahan pada DAS Batang Agam.

b. Berdasarkan klasifikasi penggunaan lahan, DAS Batang Agam didominasi oleh hutan lahan basah primer dan kebun di bagian hulu. Sedangkan di daerah hilir berupa pertanian lahan kering campur semak. Perubahan tataguna lahan pada DAS Batang Agam itu mengalami perubahan yang tidak terlalu signifikan di bagian hulu. Karena pada tahun 2010 kawasan hutan basah primer pada bagian hulu DAS memiliki persentase luas sebesar $39,44 \%$.

c. Pada Hasil tool SWAT, hasil erosivitas lahan dari tahun 2010 sampai 2019 mengalami penurunan. Hal ini disebabkan oleh erosivitas curah hujan yang angkanya turun dari tahun 2010-2019. Perubahan fungsi lahan juga mempengaruhi hasil nilai erosivitas lahan, dimana pada kasus di Batang Agam ini tidak mengalami perubahan yang terlalu signifikan. Sementara itu besarnya debit andalan yang dihasilkan sungai Batang Agam ini nilainya sangat bervariatif dan cenderung mengalami penurunan tiap tahunnya.

\section{DAFTAR PUSTAKA}

[1] Arnold JG, Kiniry JR, Srinivasan R, Williams JR, Haney EB, Neitsch SL. 2011. Soil and Water Assessment Tool : Input/Output File Documentation Version 2009. Texas: 
Agricultural Research Service and Texas AgriLife Research.

[2] Arsyad, S. 2000. Konservasi Tanah dan Air, Serial Pustaka, IPB Press, Bagian Proyek Penelitian Sumberdaya Agroklimat dan Hidrologi (BP2SAH) dan Bagian Proyek Pembinaan Perencanaan Sumber Air Ciliwung - Cisadane, 2004. Laporan Akhir Pengembangan Teknologi Dam Parit untuk Penanggulangan Banjir dan Kekeringan. Bogor: Balai Agroklimat dan Hidrologi Bogor.

[3] Asdak, Chay. 2004. Hidrologi dan Pengelolaan Daerah Aliran Sungai. Yogyakarta: Gadjah Mada University Press.

[4] As-syakur, Abd. Rahman. 2008. Prediksi Erosi Dengan Menggunakan Metode USLE Dan Sistem Informasi Geografis (SIG)Berbasis Piksel Di Daerah Tangkapan Air Danau Buyan. Bali : Pusat Penelitian Lingkungan Hidup (PPLH) Universitas Udayana.

[5] Diyyah Chairani, dkk. 2017. Perencanaan Normalisasi Dan Perkuatan Tebing Batang Agam Nagari Taruko Kota Payakumbuh. Padang : Jurusan Teknik Sipil, Fakultas Teknik Sipil dan Perencanaan, Universitas Bung Hatta.

[6] Endrawati , 2013. Analisis Debit Aliran Sungai Menggunakan Model Swat Di Sub Das Ciasem Kabupaten Subang Jawa Barat. Bogor : Departemen Manajemen Hutan Fakultas Kehutanan Institut Pertanian Bogor.

[7] Firdaus, Gunadi. 2014. Analisis Respon Hidrologi Terhadap Penerapan Teknik Konservasi Tanah di Sub DAS Lengkong Menggunakan Model SWAT. Tesis. Bogor: Institut Pertanian Bogor.
[8] Gassman PW, Reyes M, Green CH, Arnold JG. 2007. The Soil and Water Assessment Tool: Historical Development, Applications, And Future Research Directions. America: Journal of American Society Of Agricultural And Biological Engineers ISSN 00012351.

[9] Hazmy, 2018. Aplikasi Model Swat Untuk Analisis Dampak Perubahan Penggunaan Lahan Terhadap Respon Hidrologi Di Das Cibitung. Bogor : Departemen Geofisika Dan Meteorologi Fakultas Matematika Dan Ilmu Pengetahuan Alam Institut Pertanian Bogor .

[10] Hayun, Nasta Syahdiba. 2020. Pendugaan Erosi Menggunakan Model Soil And Water Assessment Tool (SWAT) Di Sub DAS Samin Kabupaten Karanganyar Dan Sukoharjo. Jawa Tengah : Universitas Gadjah Mada.

[11] Herdianto, R., Syofyan, E. R., \& Aguskamar. (2013). Pemanfaatan Informasi Topografi dan Indeks Vegetasi untuk Studi Dinamika Proses Hidrologi Daerah Aliran. Jurnal Ilmiah. POLI REKAYASA. Volume 8 Nomor 2, April 2013. ISSN : 1858-3709.

[12] Herdianto, R., Istijono, B., Syofyan, E. R., \& Dalrino.(2018). Investigation of Pangkalan Floods: Possible Reasons and Future Directions. International Journal on Advanced Science, Engineering and Information Technology, Vol.8 (2018) No. 6 , pp. 2510- 2515.

[13] Herdianto, R., Syofyan, E. R., Hanwar, S., Istijono, B., \& Dalrino. (2017). The Investigation of 1997 and 2015 El Nino Events in West Sumatera, Indonesia. International Journal on Advanced Science, Engineering and Information 
Technology, Vol. 7 (2017) No. 2, pp. 418-423.

[14] Irsyad, Fadli. 2011. Analisis Debit Sungai Cidanau dengan Aplikasi SWAT. Tesis. Bogor: Institut Pertanian Bogor.

[15] Naibaho, Melodi. 2017. Simulasi Model ArcSWAT Untuk Menganalisis Aliran Permukaan di DAS Anai Hulu. Skripsi. Padang: Universitas Andalas.

[16] Nugraheni, Aprillya. 2013. Perbandingan Hasil Prediksi Laju Erosi Dengan Metode Usle, Musle, Rusle Di Das Keduang. Surakarta : Universitas Sebelas Maret.

[17] Purnomo, Muhammad Bagus Dwi. 2019 Pemetaan Ancaman Erosi Berbasis Metode Usle Dengan Pemanfaatan Teknologi Uav Pada Kebun Alpukat (Persea Americana) Desa Karyasari, Leuwiliang, Bogor. Bogor : Departemen Ilmu Tanah Dan Sumberdaya Lahan Fakultas Pertanian Institut Pertanian Bogor

[18] Rianita, Heska. 2018. Perencanaan Pengendalian Banjir Batang Agam Kota Payakumbuh. Padang : Jurusan Teknik Sipil, Fakultas Teknik Sipil dan Perencanaan, Universitas Bung Hatta Padang.

[19] Syofyan, E. R, Saidi, A., Istijono, B., \& Herdianto, R. (2017). Model Hidrograf Akibat Perubahan Tataguna Lahan DAS Batang Kuranji (Studi Kasus Sub DAS Danau Limau Manis). POLI REKAYASA Volume 13, Nomor 1, Oktober 2017.

[20] Syofyan. E. R, Saidi, A., Istijono, B., \& Herdianto, R. (2016). Kajian Model Hidrograf Akibat Perubahan Tataguna Lahan dengan Menggunakan Data Lapangan DAS
Batang Air Dingin . POLI REKAYASA Volume 12, Nomor 1, Oktober 2016.

[21] Syofyan, E. R., Saidi, A., Istijono, B., Herdianto, R., (2018). The Hidrologic Impacts of Land Use Changes in the Middle and Upper Catchment. International Journal of Civil Engineering and Technology (IJCIET) 9 (11), 2018, pp. 997-1005.

[22] Syofyan, E. R., Saidi, A., Istijono, B., Herdianto, R., (2020). The Changes of Runoff with DEM Resolution. International Journal of Recent Technology and Engineering (IJRTE) ISSN: 2277-3878, Volume8 Issue-6, March 2020.

[23] Wulandari, Rut Desi. 2013. Simulasi Pengaruh Tata Guna Lahan Yerhadap Erosi Lahan Di Das Keduang. Surakarta : Universitas Sebelas Maret.

[24] Widodo, Ari. 2015. Metode USLE untuk Memprediksi Erosi Tanah dan Nilai Toleransi Erosi Sebuah Sistem Agricultural di Desa Genengan Kecamatan Jumantono Karanganyar. Surakarta : Universitas Sebelas Maret 